\title{
Quantification of the coralline carbonate from a Serravallian rhodolith bed of the Tertiary Piedmont Basin (Stazzano, Alessandria, NW Italy)
}

\author{
Daniela BASSO \\ University of Milano-Bicocca, \\ Geological Sciences and Geotechnologies Department, \\ Piazza della Scienza 4, I-20126 Milano (Italy) \\ daniela.basso@unimib.it \\ Francesca QUARANTA \\ Grazia VANNUCCI \\ Michele PIAZZA \\ Università di Genova, \\ Dipartimento per lo Studio del Territorio e delle sue Risorse, \\ Corso Europa 26, I-16132 Genova (Italy) \\ f.quaranta@libero.it \\ vannucci@dipteris.unige.it \\ mpiazza@dipteris.unige.it
}

KEY WORDS coralline algae, rhodolith facies,

Miocene,

Piedmont, Italy,

habitat persistence, carbonate production.
Basso D., Quaranta F., Vannucci G. \& Piazza M. 2012. - Quantification of the coralline carbonate from a Serravallian rhodolith bed of the Tertiary Piedmont Basin (Stazzano, Alessandria, NW Italy). Geodiversitas 34 (1): 137-149. http://dx.doi.org/10.5252/g2012n1a8

\section{ABSTRACT}

Digital photographs of the surface of Serravallian rhodolith-bearing strata from Stazzano (Tertiary Piedmont Basin) Italy have been elaborated by Image-J opensource software (U.S. National Institutes of Health - NIH), to obtain a map of the algal surface in each photograph. The 33 images in the $7 \mathrm{~m}$-thick outcrop, covering a total of $11.53 \mathrm{~m}^{2}$, were complemented by data on rhodolith shape, structure, composition and taphonomy. The Serravallian rhodolith body was produced in a long-lasting infralittoral sedimentary environment and then transported into deeper water by slumping. Although biological and geological definitions of rhodolith-dominated facies are inconsistent in some respects, the image analysis described here allows direct comparison of percentages of rhodolith dominance in discrete fossil rhodolith facies and their living counterparts. The procedures involved are both rapid and inexpensive, so the method appears very useful for carbonate quantification. The calculated algal cover, based only on rhodoliths $>2 \mathrm{~cm}$, ranges from 11.9 to $59.7 \%$ (mean $27.3 \%$ ). The carbonate production rate of the Serravallian rhodolith bed was probably in the range 55 to $136.3 \mathrm{~g} \mathrm{CaCO}_{3} \mathrm{~m}^{-2} \mathrm{yr}^{-1}$ as calculated for a Brazilian present-day analogue. 
MOTS CLÉS

algues rouges calcaires, faciès à rhodolithes,

Miocène,

Piémont,

Italie,

persistence de l'habitat, production carbonatée.

\begin{abstract}
RÉSUMÉ
Quantification de la production carbonatée des algues corallines basée sur l'analyse d'une barre à rhodolithes d'àge serravalien du bassin tertiaire du Piémont (Stazzano, Alessandria, nord-ouest de l'Italie).

Des photographies digitales de la surface de couches riches en rhodolithes à Stazzano (bassin tertiaire du Piémont) ont été traitées et analysées en utilisant un logiciel en open source, Image-J, développé par les U.S. National Institutes of Health (NIH), afin d'obtenir une cartographie détaillée de la surface occupée par les algues pour chacun des clichés. Dans la barre étudiée, d'environ $7 \mathrm{~m}$ de puissance, la surface cumulée couverte par les 33 images est égale à $11,53 \mathrm{~m}^{2}$. Cette information a été complétée par des données sur la forme, la structure, la composition et la taphonomie des rhodolithes. Cette barre serravallienne à rhodolithes est le résultat d'une longue période de production dans un environnement sédimentaire infralittoral relativement stable à laquelle a succédé un épisode de resédimentation dans des environnements plus profonds suite à un glissement en masse. Bien que les définitions biologiques et géologiques des faciès dominés par les rhodolithes manquent parfois de cohérence, l'analyse d'image utilisée ici permet une comparaison directe de l'abondance relative des composants dans différents faciès à rhodolithes fossiles et dans leurs équivalents modernes. Il s'agit là d'une technique très avantageuse, à la fois rapide et économique, pour quantifier la production carbonatée. La surface occupée par les algues n'est calculée que pour des rhodolithes de diamètre supérieur à $2 \mathrm{~cm}$; elle varie de 11,9 à 59,7\%, pour une valeur moyenne de 27,3\%. En conclusion, par comparaison avec un analogue actuel au Brésil, on peut estimer que la production de ce banc à rhodolithes serravalliennes devait être comprise entre 55 et 136,3 g de $\mathrm{CaCO}_{3}$ par mètre carré et par an.
\end{abstract}

\section{INTRODUCTION}

Non-geniculate coralline algae of the Order Corallinales and Sporolithales are a major calcifying component of the marine benthos in tropical to polar oceans at all depths of the photic zone (Adey \& Macintyre 1973; Kuffner et al. 2007). They are the longest-lived shallow marine organisms (Frantz et al. 2005), and are considered as one of the Earth's "Big Four" benthic communities dominated by macrophytes (Foster 2001). Their key role in the production of biogenic calcium carbonate in temperate waters, along with their global distribution, make crustose coralline algae an important element in the assessment of the global calcium carbonate budget.

The carbon cycle is straightly correlated to the global climate change, which is lowering the $\mathrm{pH}$ of ocean water and its carbonate saturation state
(Sarmiento et al. 1998; Kuffner et al. 2007). Recent research demonstrated that living coralline algae are sensitive to an increase in the ocean temperature and to acidification; both factors decrease their rates of growth and calcification with no evidence of adaptation (review in Kleypas et al. 2006). Among the calcium carbonate crystal structures formed by marine calcifying organisms in constructing their shells, liths and skeletons, natural $\mathrm{Mg}$ calcite is more soluble than calcite and can be even more soluble than aragonite, when $\mathrm{Mg}$ is very high and particle shape is favourable. Therefore Mg-calcite organisms such as coralline algae are most vulnerable to change and are among the first organisms to be affected by lower saturations (Feely et al. 2004; Orr et al. 2005; Basso 2012).

Despite their wide distribution, few attempts have been made to quantify their abundance on 


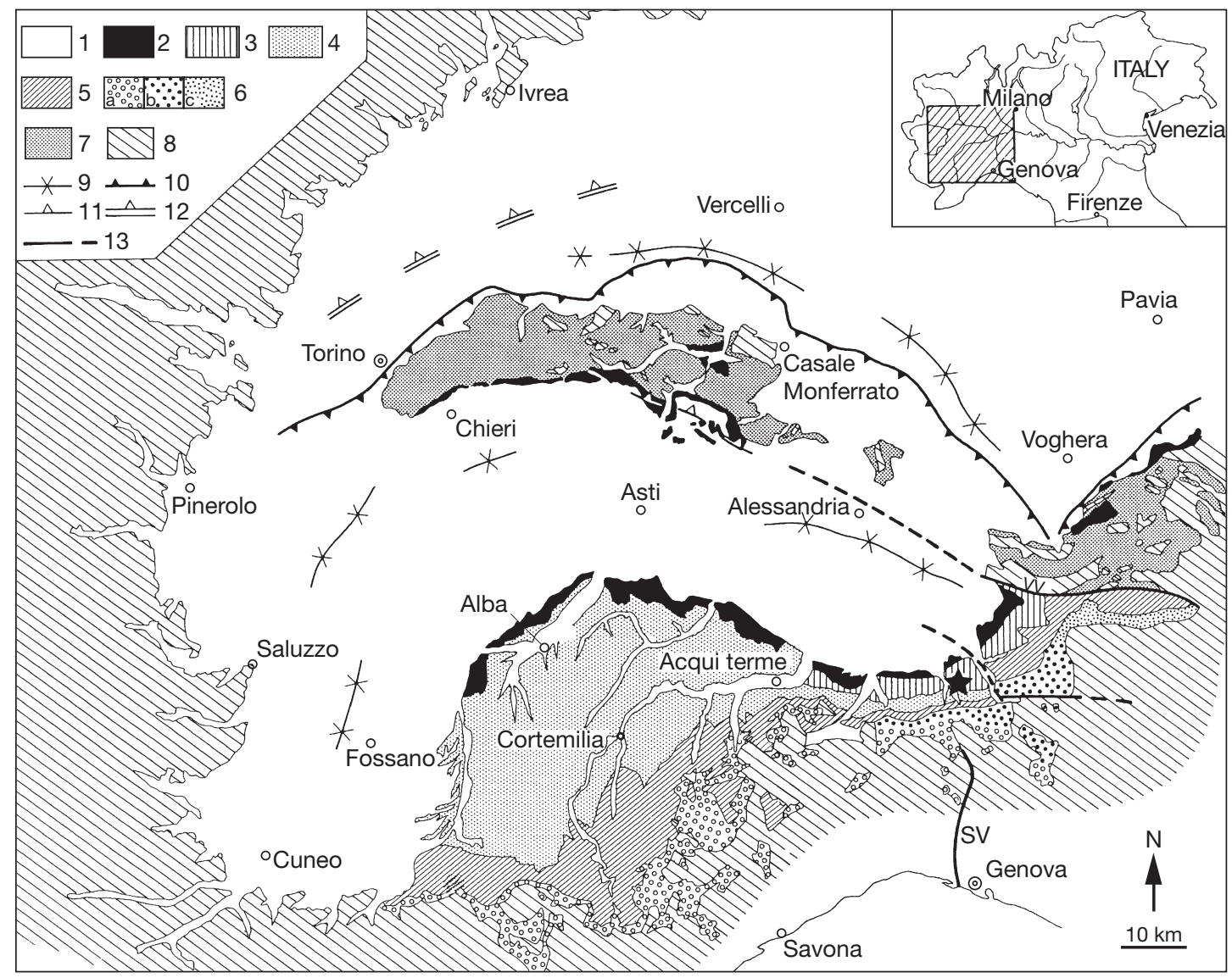

FIG. 1. - Geologic sketch map of the Tertiary Piedmont Basin, Monferrato Complex and Torino Hill, with the location of Stazzano site $(\star)$ (modified from Gelati \& Gnaccolini 1996): 1, Pliocene to Recent deposits; 2, Messinian deposits; 3, Langhian to Tortonian shelf to slope deposits; 4, Upper Burdigalian to Tortonian mainly turbiditic succession; 5, Upper Oligocene to Burdigalian turbidite systems and hemipelagic mudstones; 6 , Upper Eocene to Lower Oligocene deposits: a, alluvial to coastal conglomerates, shallow marine sandstones and hemipelagic mudstone; b, slope and base-of-slope, resedimented conglomerates; c, mainly turbidites; 7, Upper Eocene to Tortonian siliciclastic deposits of the NW Apennines - Basso Monferrato - Torino Hill wedge; 8, Alpine and Appenninic allochthonous units; 9, depocentre axis of the Plio-Quaternary basins; 10, buried thrust-front of the Torino Hill - Basso Monferrato - NW Apennines wedge; 11, buried south-vergent backthrusts of Basso Monferrato, active from Messinian onward; 12, buried, pre-Burdigalian backthrusts of Western Alps; 13, tectonic lines. Abbreviations: SV, Sestri-Voltaggio Line; VV, Villarvernia-Varzi Line.

the present-day seafloors either as a component of the living benthos or of the sediment (Gherardi 2004; Figueiredo et al. 2007; Harvey \& Bird 2008; Riul et al. 2009).

Before the definition of Bosellini \& Ginsburg (1971) and the review of Adey \& Macintyre (1973), rhodoliths were largely overlooked in geological literature. More recently, the geological nomenclature to indicate the fossil counterparts of living rhodolith beds has included a suite of terms such as rhodolith facies, coralline algal facies, rhodolith rudstone and floatstone, oncolithic rudstone, rhodolith pavements (= densely packed rhodolith rudstone), coralline algal nodule limestone, maerl pavement, red algal clast rudstone and coralline branch rudstone and floatstone (among others: Bosence \& Pedley 1979; Manker \& Carter 1987; Fravega et al. 1993; Henrich \& Freiwald 1995; Nebelsick \& Bassi 2000; Rasser \& Piller 2004; Di Credico et al. 2004; Basso et al. 2006; Hetzinger 


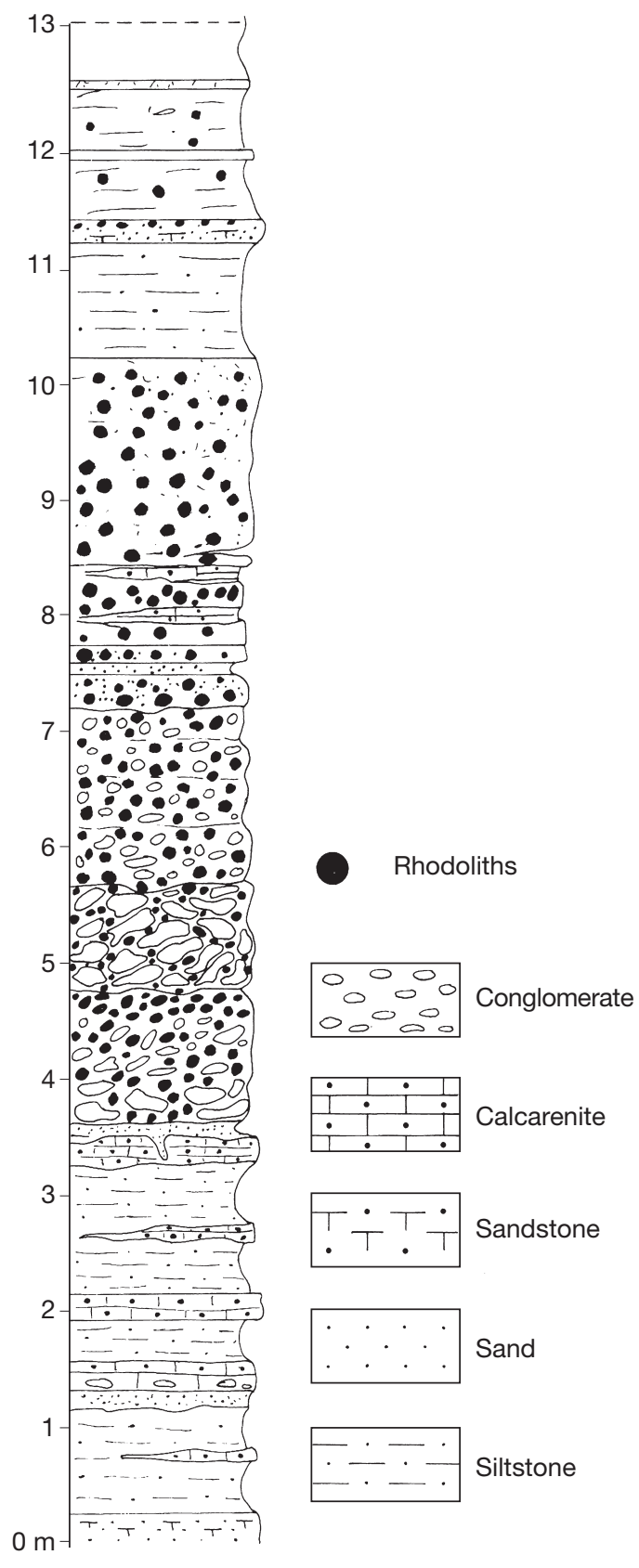

FIG. 2. - Simplified stratigraphic section of Stazzano, Tertiary Piedmont Basin, Italy (modified from Fravega \& Vannucci 1982).

et al. 2006; Webster et al. 2006; Titschack et al. 2008; Bassi et al. 2009). However, quantitative data on fossil rhodolith deposits are still lacking, thus preventing an appropriate use of the fossil record for modelling the future response of the oceans to rising temperature and $\mathrm{CO}_{2}$ concentration.

Moreover, the possibility of quantitative comparisons among fossil coralline deposits is hampered by the heterogeneity of procedures, used for the description and calculation of the algal contribution to the total carbonate. There is no consensus on the sampling strategy to be used, including: visual estimate of percentage cover during field work; random sampling and laboratory-based examination of sediment samples; random extraction of rhodoliths from strata; counts along transects, etc. Some of these techniques imply a large degree of subjectivity (e.g., in situ visual estimates or random extraction).

Finally, any comparison between modern marine sediments and the geologic record is complicated by the use of sectorial terms and definitions proposed by researchers with various cultural backgrounds.

Quantification is the only practicable strategy to do away with subjectivity, equivocal or ambiguous nomenclature, and inhomogeneous descriptions of coralline-dominated sediment, and to provide data suitable for biogeochemical modelling on a planetary scale (Basso 2012). In this perspective, the scientific community is challenged by the necessity of testing new methods and techniques to produce quantitative data from various geologic settings and present-day environments. We propose here a new method for the quantification of a fossil rhodolith bed, tested in a Serravallian outcrop of Stazzano (Alessandria, Italy).

\section{THE TERTIARY PIEDMONT BASIN}

The Tertiary Piedmont Basin (TPB) parallels the Piedmont-Liguria border in northwestern Italy (Fig. 1). The TPB is a late- to post-orogenic basin that evolved in a piggy-back position on the Monferrato thrust belt. Its deposition was strongly controlled by tectonic and eustatic events (Gelati \& Gnaccolini 1988; Mutti et al. 1995; Giglia et al. 1996; Capponi et al. 2001, 2009).

Marine sediments (Upper Eocene-Upper Miocene) predominate in the basin fill which unconformably overlies the Ligurian Alps, the Sestri-Voltaggio Zone 


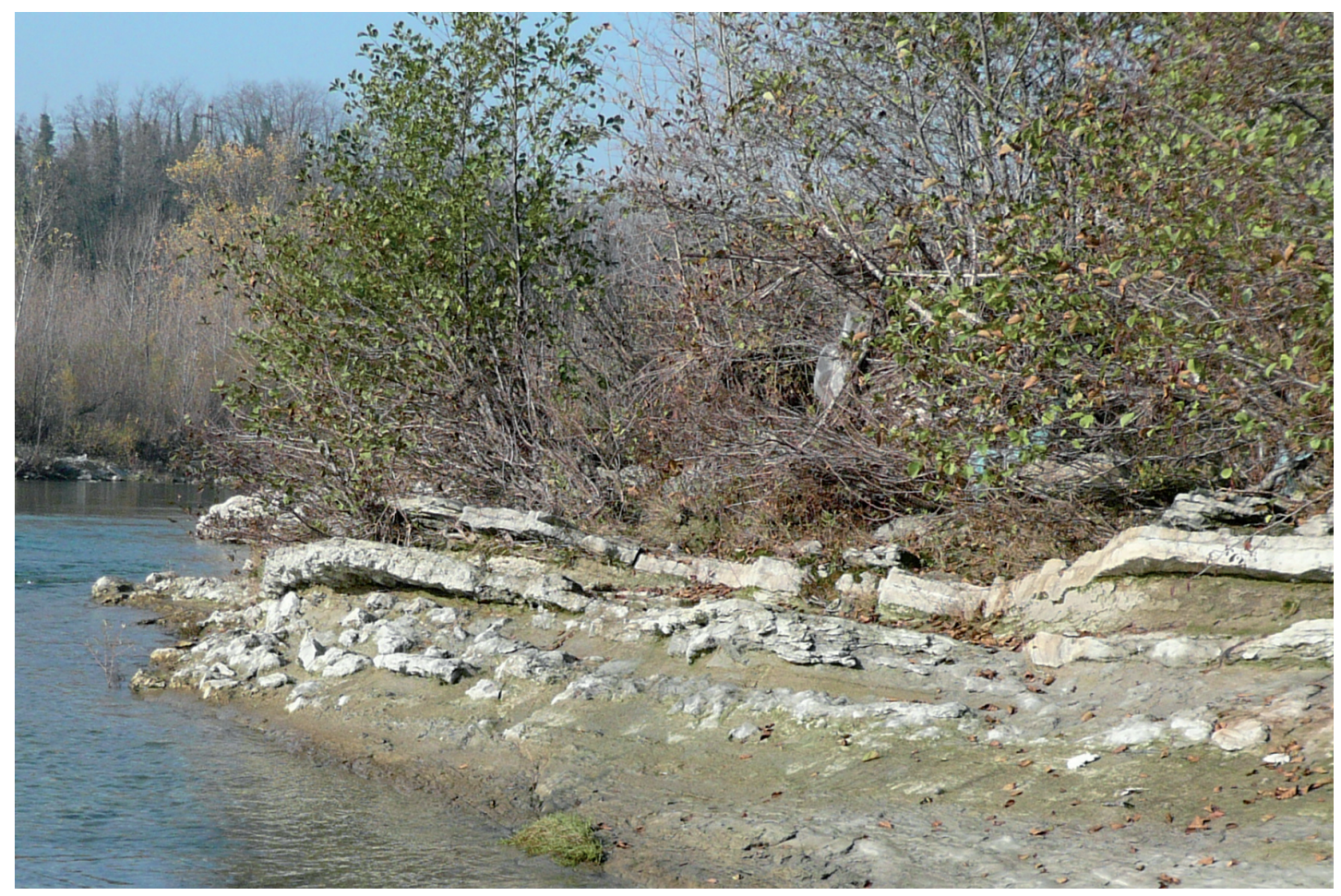

FIG. 3. - View of the rhodolith-rich stratigraphic section of Stazzano (Tertiary Piedmont Basin, Italy) along the Scrivia River.

and the northwestern sector of the northern Apennines. The early stage of sedimentation of the TPB includes a siliciclastic deposition that evolved from Upper Eocene breccias through Lower Oligocene conglomerate to Upper Oligocene-Lower Miocene sandstone and silty-marl.

These units, grouped into several formations, record a pre-transgressive and transgressive phase (time-transgressive from the eastern to the western sectors), characterized by the deposition of alluvial fan and fan delta siliciclastic conglomerates and sandstones, shallow-marine coarse to fine grained siliciclastics, and reef limestones (Gelati \& Gnaccolini 1988; Turco et al. 1994; Mutti et al. 1995; Quaranta et al. 2009) (Fig. 2). These units are affected by long-wavelength open fold; their axes trend N-S and their vergence is towards the east. Locally, deformations evolve into thrusts which caused overlap of the metamorphic basement onto the TPB sediments (Capponi et al. 2001, 2009).
In the Miocene, at least the northern parts of the TPB evolved in a piggy-back position on the Monferrato thrust belt. This evolution is strictly connected with the Corsica-Sardinia roto-translation and the related tectonic events that formed the arcuate morphology of the western and Ligurian Alps (Giglia et al. 1996). The Lower Miocene tectonic activity originated erosional surfaces, angular unconformities, turbidites, slumpings and channelling of shallow sediments with syn-sedimentary foldings (Ghibaudo et al. 1985; Gelati \& Gnaccolini 1988; Giglia et al. 1996). These bodies are covered by Langhian slope pelites, that grades upwards to shelf sandstone and fine conglomerate (Serravallian) that testify a shallowing event. They are followed by a new deepening phase with the deposition of sandy-silty and silty sediments with slumpings and channelling of shallow-water sediments caused by a regional tectonic activity (top of Serravallian section; Ghibaudo et al. 1985; Gelati \& Gnaccolini 1988; Giglia et al. 1996). 


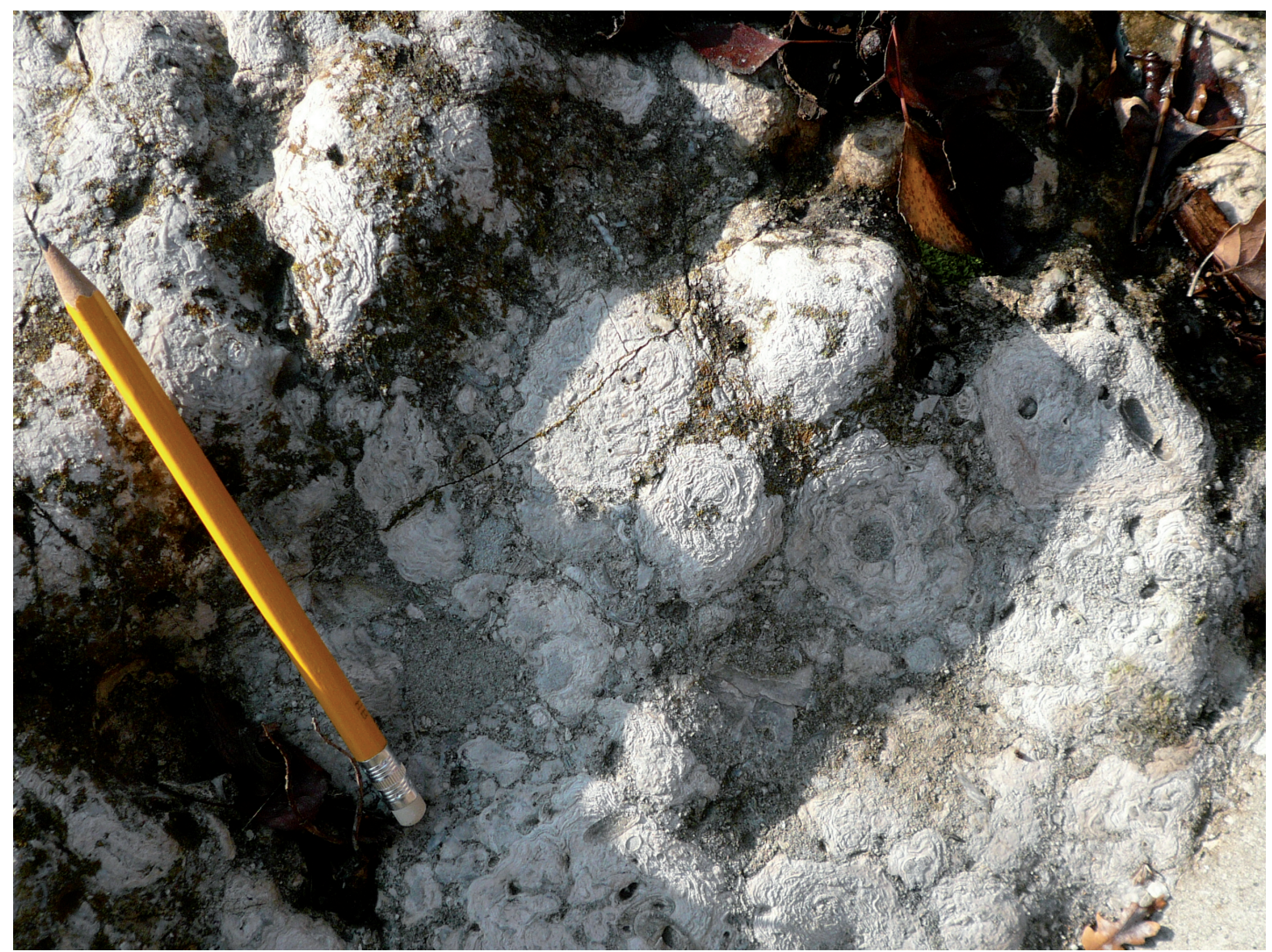

FIG. 4. - Pluricentimetric rhodoliths of the stratigraphic section of Stazzano (Tertiary Piedmont Basin, Italy).

The TPB depositional history ends with the sedimentation of Tortonian marine pelites grading to pre-evaporitic deposits; these sediments are affected by intraformational unconformities, debris flows, and slumps (Ghibaudo et al. 1985; Gelati \& Gnaccolini 1988; Giglia et al. 1996).

\section{THE SERRAVALLIAN RHODOLITHS OF STAZZANO}

The portion of Serravallian section in the central part of the TPB shows outer shelf silty marl and siltstone grading upwards to inner shelf sandstone (hybrid arenites) and fine conglomerate, followed by sandy-silty and silty sediments, in which slumps and conglomeratic or biocalciruditic lenticular bodies are interbedded (Ghibaudo et al. 1985) (Figs 2; 3). The Stazzano lithostratigraphic section (upper Serravallian, total thickness about 13 $\mathrm{m}$, Serravalle Sandstone Formation) is a classic exposure of the uppermost levels of the Serravalle Sandstone Formation. There it is possible to observe the channels filled by rhodolithic rudstone and floatstone cutting the silty deposits. The maximum thickness of the rhodolith-bearing outcrop is $7 \mathrm{~m}$ and the horizontal exposed surface has an area of about $40 \mathrm{~m}^{2}$. The rhodolithic bodies of Stazzano are a slumped mass derived from the inner shelf and coastal area; similar mass movements caused by gravity flow characterize the Late Serravallian succession in the Serravalle Scrivia sector of the TPB (Vervloet 1966; Fravega \& Vannucci 1982). 

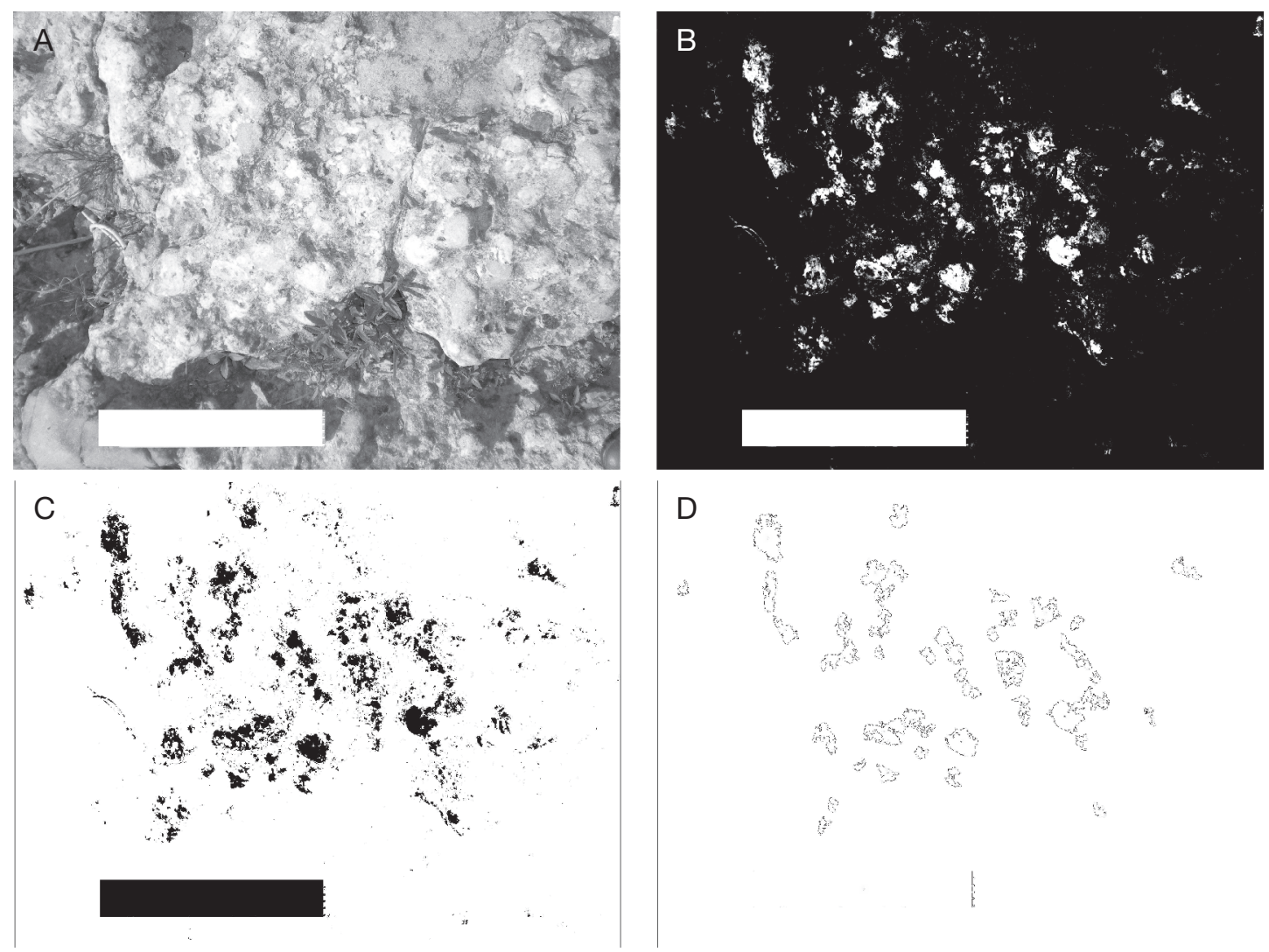

FIG. 5. - Steps in image processing for rhodolith cover quantification: A, conversion of the original colour picture into 8 bit gray scale; B, increased brightness and contrast; C, enhanced contrast and set threshold to allow object surface selection; D, final step showing the contour of rhodoliths for area calculation. Ruler for scale is $24 \mathrm{~cm}$.

The fauna includes echinoids, brachiopods, molluscs, annelids, bryozoans, and benthic and planktonic foraminifers (Fravega \& Vannucci 1982).

The rhodoliths from this section have spheroidal (93\%) and ellipsoidal (7\%) shapes (Vannucci 1980; Fravega \& Vannucci 1982; Fravega et al. 1993; Quaranta et al. 2009). Most rhodoliths have long axes (see Bosellini \& Ginsburg 1971) ranging between 2 and $6 \mathrm{~cm}$, but rhodoliths up to $10 \mathrm{~cm}$ are not rare (Fig. 4). The internal structure of rhodoliths is laminar (mainly concentric) or laminar-columnar (94\%) and subordinately columnar or branching $(6 \%)$, with the minority form restricted to the innermost part of the coating sequence. They have a bioclastic nucleus $(96 \%)$ that rarely is a lumpy to fruticose coralline alga (4\%).
The algal assemblage is dominated by Lithophylloideae (41.5\%), mainly Lithophyllum Philippi (40.1\%) and rare Titanoderma Nägeli in Nägeli \& Cramer (1.4\%). Melobesioideae (33.1\%) are represented by several species of Lithothamnion Heydrich and/or Phymatolithon Foslie (16.2\%) and Mesophyllum Lemoine (16.9\%). Mastophoroideae represent up to $24 \%$ of the total assemblage, while Sporolithales (1.4\%) are occasional. The most abundant species are Lithophyllum racemus (Lamarck) Foslie, Mesophyllum gignouxii Lemoine and Mesophyllum sancti-dyonisii Lemoine. Encrusting-warty (54\%) or encrusting (33\%) growth forms are dominant; warty-lumpy to lumpy $(10 \%)$ and fruticose (3\%) growth forms are rare. The available literature (Vannucci 1980; Fravega \& Vannucci 1982; Fravega 
et al. 1993; Quaranta et al. 2009) indicates that the rhodoliths formed in warm waters, under mid-high energy conditions on the soft bottoms of the inner part of the infralittoral zone.

\section{METHODS}

33 sites have been photographed and analyzed, 26 are along bedding planes and 7 are on subvertical surfaces across the strata.

A suite of digital photographs of the surface of rhodolith-bearing strata has been obtained and elaborated by Image-J open-source software (U.S. National Institutes of Health - NIH), in order to produce a map of the algal surface in each photograph.

The Image-J procedure for the quantification of algal carbonate from photographs consists of seven steps (Fig. 5): 1) select picture and set scale and unit to obtain true distance; 2) remove from the photograph objects not to be counted (i.e. leaves, metric scale); 3) convert the photograph into 8 bit grey scale (Fig. 5A); 4) increase brightness and contrast (Fig. 5B); 5) threshold the image to enhance contrast and to allow surface selection (Fig. 5C); 6) enter minimum size of particle to be counted $(2 \mathrm{~cm}) ; 7)$ start process of particle analysis (Fig. 5D). The result is expressed as area of the photograph occupied by algal carbonate, and its percentage on the total area.

The minimum particle size has been set at $2 \mathrm{~cm}$ for two reasons: 1) $2 \mathrm{~cm}$ is the size of the smallest rhodoliths; and 2) the non-algal carbonate bioclasts in the rhodolith rudstone/floatstone matrix, which could falsify the results of the computerized image analysis, do not exceed $2 \mathrm{~cm}$ in diameter.

The rhodolith-embedding limestone (grains $<2 \mathrm{~cm}$ ) has been analyzed in thin section, in order to assess the contribution of coralline algae to the original sediment. Semi-quantitative estimates of the distribution of the components in the rhodolith-embedding limestone were performed under a binocular microscope using a $25 \times$ magnification, as recommended by Baccelle \& Bosellini (1965) and Flügel (1982). The textural classification used to characterize the microfacies follows Embry \& Klovan (1971).

\section{RESULTS}

The photographs analysed a total surface of $11.53 \mathrm{~m}^{2}$ (Table 1 ). The area covered by the 26 stations located on the bedding planes is about $9.8 \mathrm{~m}^{2}$, and the area covered by the 7 stations sited across the strata is about $1.7 \mathrm{~m}^{2}$. The number of rhodoliths at each station with a diameter larger or equal to $2 \mathrm{~cm}$ identified in photographs ranges from 10 to 268, with a mean abundance of about 102 (Table 1). The areas of the photographs range from about 443 to about $9502 \mathrm{~cm}^{2}$. The percentage of algal cover, based only on grains $>2 \mathrm{~cm}$ in diameter, ranges from 11.9 to $59.7 \%$, of the total area (mean 27.3\%; Table 1). The abundance of rhodoliths and the percentage of algal cover on the bedding planes and on the subvertical surfaces normal to the bedding plane is similar in all respects. A mean density of 273 rhodoliths per $\mathrm{m}^{-2}$ has been calculated.

The rhodoliths are embedded in a calcite-cemented hybrid arenite to biosparite or biosparrudite. The carbonate grains of the matrix (Embry \& Klovan 1971) are biogenic, and are mainly coralline fragments (in most cases about $10-25 \%$ of the total) and skeletal remains of molluscs up to $5 \mathrm{~mm}$ long. Among benthic foraminifers, rotaliids are abundant while miliolids, Amphistegina d'Orbigny, 1826, unidentified agglutinated and encrusting foraminifers are less common. Fragments of annelids, bryozoans, and echinoids are common. Planktonic foraminifers are rare, but are more abundant above and below the rhodolithic bodies. The non-carbonate fraction of the matrix is composed of sand-sized grains of quartz, rock fragments and rare feldspar. The sediment trapped in the algal layers within the rhodoliths has the same texture and composition as that of the embedding matrix.

\section{DISCUSSION}

Rhodolith beds (including maerl beds; Bosellini \& Ginsburg 1971; Bosence 1976; Birkett et al. 1998) are defined in present-day environment as marine soft-substrates with a $>10 \%$ cover of living coralline thalli (Steller et al. 2003). 
TABLE 1. - Rhodolith cover obtained from image analysis of 33 sites in the Serravallian outcrop of Stazzano (Tertiary Piedmont Basin, Italy). Only rhodoliths larger than $2 \mathrm{~cm}$ have been considered.

\begin{tabular}{|c|c|c|c|c|c|}
\hline & n rhodoliths & Analyzed area $\left(\mathrm{cm}^{2}\right)$ & rhodoliths (n m-2) & Algal area $\left(\mathrm{cm}^{2}\right)$ & Algal cover (\%) \\
\hline \multicolumn{6}{|c|}{ Sites on the bedding plane } \\
\hline 1 & 264 & 9497.2 & 278 & 1432.2 & 15.08 \\
\hline 2 & 255 & 9081.7 & 281 & 3741.7 & 41.2 \\
\hline 3 & 198 & 7059.7 & 280 & 840.1 & 11.9 \\
\hline 4 & 134 & 3642.5 & 368 & 590.1 & 16.2 \\
\hline 5 & 268 & 6150.9 & 436 & 1205.6 & 19.6 \\
\hline 6 & 241 & 5747.1 & 419 & 1862.1 & 32.4 \\
\hline 7 & 210 & 8714.5 & 241 & 3921.5 & 45.0 \\
\hline 8 & 248 & 6709.6 & 370 & 1670.7 & 24.9 \\
\hline 9 & 244 & 9502.3 & 257 & 3354.3 & 35.3 \\
\hline 10 & 137 & 4955.1 & 276 & 2348.7 & 47.4 \\
\hline 11 & 89 & 2759.4 & 322 & 331.1 & 12.0 \\
\hline 12 & 44 & 1671.5 & 263 & 436.3 & 26.1 \\
\hline 13 & 74 & 2784.2 & 266 & 654.3 & 23.5 \\
\hline 14 & 79 & 2879.1 & 274 & 382.9 & 13.3 \\
\hline 15 & 17 & 860.8 & 197 & 174.7 & 20.3 \\
\hline 16 & 108 & 2374.7 & 455 & 579.4 & 24.4 \\
\hline 17 & 53 & 1412.9 & 375 & 317.9 & 22.5 \\
\hline 18 & 29 & 1927.7 & 150 & 1010.1 & 52.4 \\
\hline 19 & 26 & 1002.9 & 259 & 598.7 & 59.7 \\
\hline 20 & 44 & 2044.2 & 215 & 598.9 & 29.3 \\
\hline 21 & 75 & 2660.8 & 282 & 348.6 & 13.1 \\
\hline 28 & 13 & 752.4 & 173 & 203.9 & 27.1 \\
\hline 29 & 16 & 606.8 & 264 & 176.0 & 29.0 \\
\hline 30 & 35 & 995.3 & 352 & 204.0 & 20.5 \\
\hline 31 & 13 & 875.2 & 148 & 124.3 & 14.2 \\
\hline 33 & 32 & 1024.4 & 312 & 219.2 & 21.4 \\
\hline \multicolumn{6}{|c|}{ Sites normal to bedding plane } \\
\hline 22 & 125 & 4142.6 & 302 & 608.7 & 14.7 \\
\hline 23 & 122 & 5078.2 & 240 & 2686.4 & 52.9 \\
\hline 24 & 28 & 1653.3 & 169 & 783.6 & 47.4 \\
\hline 25 & 23 & 1524.6 & 151 & 437.6 & 28.7 \\
\hline 26 & 10 & 443.4 & 225 & 131.7 & 29.7 \\
\hline 27 & 63 & 2746.9 & 229 & 357.1 & 13 \\
\hline 32 & 38 & 1985.1 & 191 & 331.5 & 16.7 \\
\hline \multicolumn{6}{|l|}{ Total } \\
\hline 33 & 3355 & 115266.9 & & 32664.2 & \\
\hline Min & 10 & 443.4 & 148 & 124.3 & 11.9 \\
\hline Max & 268 & 9502.3 & 455 & 3921.5 & 59.7 \\
\hline Mean & 101.7 & 3492.9 & 273 & 989.8 & 27.3 \\
\hline (s.d.) & (88.4) & $(2817.7)$ & (81) & (1070) & (13.4) \\
\hline
\end{tabular}

The surfaces of rhodolith beds are composed of a mixture of dead and living thalli, but few ecological studies have commented on the proportions of live to dead rhodoliths. In Western Port (southern Australia) live rhodoliths on the seafloor are reported as $15-37 \%$ of a total $400-600$ rhodoliths $\mathrm{m}^{-2}$ (Harvey $\&$ Bird 2008). In the Abrolhos Bank (tropical
Brazil), live rhodoliths are about $20 \%$ of the total (Figueiredo et al. 2007). Elsewhere the live/dead ratio is variable, also depending on the health of the local corallines.

On the basis of the geological definition of rhodolith (a red algal nodule $>2 \mathrm{~mm}$ ) and rudstone (> 10\% grains larger than $2 \mathrm{~mm}$ in contact), a 
rhodolithic rudstone is defined by the percentage of rhodoliths, whilst in biology, the definition of rhodolith bed is based on the percentage of seafloor covered by living thalli. Rhodolith pavements are an almost continuous surface made of closely packed rhodoliths (Bosence \& Pedley 1979; Rasser \& Piller 2004; Bassi et al. 2009) that likely corresponded to true rhodolith beds, however, the geological and biological terms differ significantly when dealing with rudstone and floatstone that contain only small rhodoliths. From available data on dead/live ratios in modern rhodolith beds, a rhodolith rudstone with a low percentage (number of grains) of small rhodoliths would not be considered a rhodolith bed, because the cover of live corallines was probably much lower than $10 \%$. Further problems arise from the use of heterogenous techniques to describe and sample rhodolith beds, although a rigorous and unequivocal sampling method has been recently proposed (Steller et al. 2007).

On the contrary, no interpretation or assumption is required by the image analysis procedure described here, that permits a low-cost, rapid, and objective comparison of rhodolith percentages in various fossil rhodolith facies and with those of their living counterparts.

The similar variability of rhodolith distribution and composition in the bedding planes and subvertical surfaces demonstrate the homogeneity of the Serravallian rhodolith bed. The rhodolithembedding matrix and the sediment trapped within the rhodoliths have the same origin, thus confirming that all the skeletal component of the $7 \mathrm{~m}$-thick rhodolithic body represents the carbonate produced by a single infralittoral sedimentary environment (Vannucci 1980; Fravega \& Vannucci 1982; Fravega et al. 1993).

Literature concerning present-day infralittoral rhodolith beds around the world reports rhodolith abundance ranging from 24 to 10676 rhodoliths $\mathrm{m}^{-2}$ (Riul et al. 2009) and growth rates of infralittoral rhodoliths in warm-water between 0.25 and $0.6 \mathrm{~mm}$ $\mathrm{yr}^{-1}$ (review in Foster 2001).

Existing coralline associations in infralittoral temperate-warm environments can be regarded as a useful basis of comparison for the interpretation of our Serravallian example. The search for analogues should concentrate on marine areas where climatic and oceanographic conditions prevent the development of scleractinian reef-building corals, so that red calcareous algae become dominant. Such a depositional environment is demarcated by the present-day geographic distribution of the "rhodalgal" facies (Carannante et al. 1988). In particular, dominant Lithophylloideae associated with Hapalidiaceae are abundant in the temperate-warm infralittoral rhodolith beds along the Atlantic coast of southern Brazil (State of Santa Catarina), where the coralline flora, the benthic association and the carbonate production have been investigated (Gherardi 2004; Rocha et al. 2006; Pasceli et al. 2009). In the Santa Catarina rhodolith beds, the living and mostly spheroidal rhodoliths and their fragments cover from 20 to $40 \%$ of the sandy seafloor along transects ranging from 7 to $20 \mathrm{~m}$ in depth. Living rhodoliths are associated with dead corallines that make up 15 to $35 \%$ of the cover, for a total coralline cover of 35 to $68 \%$ (Gherardi 2004). Gherardi (2004), following Bosence (1980) and Freiwald \& Henrich (1994) estimated that the Santa Catarina rhodolith beds produce carbonates at a rate of 55 to $136.3 \mathrm{~g} \mathrm{CaCO}_{3} \mathrm{~m}^{-2} \mathrm{yr}^{-1}$. The cover percentage of the Santa Catarina living rhodoliths largely overlaps our data. Interestingly, both Gherardi's (2004) and our results are based on photographic transects where only macroscopic grains can be confidently identified during image processing.

At the growth rate of $0.25-0.6 \mathrm{~mm} \mathrm{yr}^{-1}$ a $2 \mathrm{~cm}$ rhodolith forms in 34-80 years, and a $10 \mathrm{~cm}$ rhodolith probably needs $150-400$ years to form. This computation is intentionally conservative, since we disregard the possibility of a radial growth of the rhodolith, which could reach a $10 \mathrm{~cm}$ diameter in a much shorter time. Coralline algae can survive a period of burial, but after some months permanent cover kills them (Scoffin et al. 1985; Basso 1998; Basso et al. 2009). Therefore, the slumped Serravallian rhodoliths suggest that the rate of sedimentation in the source area was very low so that rhodoliths did not undergo complete burial for several decades or centuries. This hypothesis is supported by previous paleontological investigations that found no evidence of significant discontinuities of growth (sensu Basso et al. 2009) or of erosional surfaces inside rhodoliths (Vannucci 1980; Fravega \& Vannucci 1982; Fravega 
et al. 1993). Since growth appears to have been regular and more or less uninterrupted, it is likely that rhodoliths of any size up to about $10 \mathrm{~cm}$ were living and growing on the biodetrital Serravallian seafloor, as modern rhodoliths do. Thus, we can assume that the paleoenvironment was more or less stable, with pluricentimetric rhodoliths flourishing on the infralittoral Serravallian seafloor for at least several centuries over a wide area, large enough to provide the bulk funneled in the channel network. In particular, it is possible to calculate that a $10-\mathrm{cm}$ thick rhodolith bed occupying a surface of $10 \mathrm{~m}^{2}$ produced in one to four centuries the equivalent of $1 \mathrm{~m}^{3}$ of rhodolith deposit.

\section{CONCLUSIONS}

Image analyses of $11.53 \mathrm{~m}^{2}$ of the $7 \mathrm{~m}$-thick Serravallian rhodolithic body, together with the information available on rhodolith shape, structure, composition and taphonomy support the conclusion that the rhodolith body was produced in an infralittoral sedimentary environment on a Serravallian platform that no longer exists. Large masses of this infralittoral sediment were transported to deeper water by slumping. For biologists the term rhodolith bed is restricted to rhodolith-dominated benthic assemblages with more than $10 \%$ of living algal cover, whilst the geological terms rhodolith rudstone and floatstone are based on the number of rhodoliths that are more than $2 \mathrm{~mm}$ in diameter, rather than surface coverage. Therefore, the term rhodolith bed is more restrictive than rhodolith rudstone, because in the fossil the surface covered by live algae cannot be determined, and thus the two different approaches cannot be directly compared.

Image analysis permits direct comparison of the rhodolith dominance across a suite of fossil rhodolith facies and their living counterparts, the present-day rhodolith beds. This method also appears very useful for carbonate quantification through the identification of dominant macroscopic elements. Image analysis allows to use the traditional, sample-based, paleoecological approach (sediment/sedimentary rock analysis, species identification, ecology and paleoecology of the assemblage) as a voucher to the interpretation and quantification of the entire body of rock, provided that homogeneous features are assessed.

The rate of carbonate production for the Serravallian rhodolith bed was probably in the range of 55 to $136.3 \mathrm{~g} \mathrm{CaCO}_{3} \mathrm{~m}^{-2} \mathrm{yr}^{-1}$ as calculated for a present-day analogue (Gherardi 2004). A 10-cm thick rhodolith bed over a surface of $10 \mathrm{~m}^{2}$ produced the equivalent of $1 \mathrm{~m}^{3}$ of rhodolith deposit in 150-400 years. Although we cannot constrain the duration/surface of the rhodolith source area in our example, we feel that this kind of computational exercise could be profitably applied to autochtonous fossil deposits, in order to provide a useful term of comparison in modelling the long-term response of present-day rhodolith beds (Foster 2001; Steller et al. 2003).

\section{Acknowledgements}

We warmly thank D. Gherardi, L. Simone and V. Malécot for their critical revision of the manuscript. N. Sanders improved the English language. This research has been supported by the Research funds of the universities of Genova and MilanoBicocca (Fondi di Ateneo).

\section{REFERENCES}

AdeY W. H. \& Macintyre I. G. 1973. - Crustose coralline algae: a re-evaluation in the geological sciences. Geological Society of America Bulletin 84: 883-904.

BACCELLE L. \& Bosellini A. 1965. — Diagrammi per la stima visiva della composizione percentuale nelle rocce sedimentarie. Annali dell'Università di Ferrara (N.S.) sez. 9 (4): 59-62.

Bassi D., Nebelsick J. H., Checconi A., Hohenegger J. \& IRYU Y. 2009. — Present-Day and fossil rhodolith pavements compared: their potential for analysing shallow-water carbonate deposits. Sedimentary Geology 214: 74-84.

BASSO D. 1998. - Deep rhodolith distribution in the Pontian Islands, Italy: a model for the paleoecology of a temperate sea. Palaeogeography, Palaeoclimatology, Palaeoecology 137: 173-187.

BASso D. 2012. - Carbonate production by calcareous red algae and global change, in BASSO D. \& GrANIER B. (eds), Calcareous algae and global change: from identification to quantification. Geodiversitas 34 (1): 13-33. http://dx.doi.org/10.5252/g2012n1a2 
Basso D., Morbioli C. \& Corselli C. 2006. Rhodolith facies evolution and burial as response to Holocene transgression at the Pontian Islands shelf break, in Pedley H. M. \& Carannante G. (eds), Cool-Water carbonates: depositional systems and palaeoenvironmental control. Geological Society of London, Special Publication 255: 23-34.

BASSO D., NALIN R. \& NelSON C. S. 2009. - ShallowWater Sporolithon rhodoliths from North Island (New Zealand). Palaios 24 (2-3): 92-103.

Birkett D. A., Maggs C. \& Dring M. J. 1998. Maërl. Volume V. An overview of dynamic and sensitivity characteristics for conservation management of marine SACs. Scottish Association for Marine Science (UK Marine SACs Project), Belfast, 116 p.

Bosellini A. \& Ginsburg R. N. 1971. - Form and internal structure of recent algal nodules (rhodolites) from Bermuda. Journal of Geology 79: 669-682.

Bosence D. W. J. 1976. - Ecological studies on two unattached coralline algae from western Ireland. Palaeontology 19: 365-395.

BOSENCE D. W. J. 1980. - Sedimentary facies, production rates and facies models for recent coralline algal gravels, Co. Galway, Ireland. Geological Journal 15 (2): 91-111.

Bosence D. W. J. \& Pedley H. M. 1979. — Deuxième symposium international sur les algues fossiles. Bulletin $d u$ centre de recherche, exploration et production Elf-Aquitaine 3: 463-470.

Capponi G., Crispini L., Piazza M. \& Amandola L. 2001. - Field constraints to the Mid-Tertiary kinematics of the Ligurian Alps. Ofioliti 26 (2b): 409-416.

Capponi G., Crispini L., Federico L., Piazza M. \& FABBRI B. 2009. - Late Alpine tectonics in the Ligurian Alps: constraints from the Tertiary Piedmont Basin conglomerates. Geological Journal 44: 211-244. http://dx.doi.org/10.1002/gj.1140

Carannante G., Esteban M., Milliman J. D. \& Simone L. 1988. - Carbonate lithofacies as paleolatitude indicators: problems and limitations. Sedimentary Geology 60: 333-346.

Di Credico N., Fravega P., Giammarino S., Piazza M. \& VANnUCCI G. 2004. - Algal assemblages of Cala Pisana Member, Lampedusa Formation (Upper Miocene - Island of Lampedusa, Pelagian Block). Bollettino Accademia Gioenia di Scienze naturali di Catania 37 (364): 217-243.

Embry A. F. \& Klovan J. E. 1971. — A Late Devonian reef tract on northeastern Banks Island, Northwest Territories. Bulletin of Canadian Petroleum Geology 19: 730-781.

Feely R. A., Sabine C. L., Lee K., Berelson W., KleyPAS J., FABRY V. J. \& Millero F. J. 2004. — Impact of anthropogenic $\mathrm{CO}_{2}$ on the $\mathrm{CaCO}_{3}$ system in the ocean. Science 305: 362-366.

Figueiredo M. A. de O., Santos de Menezes K., Costa-Paiva E. M. \& Ventura C. R. R. 2007. -
Experimental evaluation of rhodoliths as living substrata for infauna at the Abrolhos Bank, Brazil. Ciencias Marinas 33: 427-440.

FLÜGEL E. 1982. - Microfacies Analysis of Limestones. Springer-Verlag, Berlin, 633 p.

FosTeR M. S. 2001. - Rhodoliths: between rocks and soft places. Journal of Phycology 37: 659-667.

Frantz B. R., Foster M. S. \& Riosmena-Rodriguez R. 2005. - Clathromorphum nereostratum (Corallinales, Rhodophyta): the oldest alga? Journal of Phycology 41: 770-773.

Fravega P. \& Vannucci G. 1982. - Significato e caratteristiche degli episodi a rhodoliti al "top" del Serravalliano tipo. Geologica Romana 21: 705-715.

Fravega P., Piazza M. \& VAnNucci G. 1993. - Importance and significance of the rhodolithic bodies in the miocenic sequences of Tertiary Piedmont Basin, in Barattolo F., De Castro P. \& Parente M. (eds), Studies on fossil benthic algae. Bollettino della Società Paleontologica Italiana spec. vol. 1: 197-210.

Freiwald A. \& Henrich R. 1994. - Reefal coralline algal build-ups within the Arctic Circle: morphology and sedimentary dynamics under extreme environmental seasonality. Sedimentology 41: 963-984.

Gelati R. \& GNacColini M. 1988. - Sequenze deposizionali in un bacino episuturale, nella zona di raccordo tra Alpi ed Appennino Settentrionale. Atti ticinesi di Scienze della Terra 31: 340-350.

GELATI R. \& GNACCOLINI M. (with contribution by Maioli A.) 1996. - The stratigraphic record of Oligocene-Early Miocene events at the south-western end of the Piedmont Tertiary Basin. Rivista Italiana di Paleontologia e Stratigrafia 102 (1): 65-76.

GHerardi D. F. M. 2004. - Community structure and carbonate production of a temperate rhodolith bank from Arvoredo Island, southern Brazil. Brazilian Journal of Oceanography 52 (3-4): 207-224.

Ghibaudo G., Clari P. \& Perello M. 1985. — Litostratigrafia, sedimentologia ed evoluzione tettonicosedimentaria dei depositi miocenici del margine sud-orientale del Bacino Terziario Ligure-Piemontese (Valli Borbera, Scrivia e Lamme). Bollettino della Società Geologica Italiana 104: 349-397.

Giglia G., Capponi G., Crispini L. \& Piazza M. 1996. - Dynamics and seismotectonics of the WestAlpine arc. Tectonophysics 267: 143-175.

Harvey A. S. \& Bird F. L. 2008. — Community structure of a rhodolith bed from cold-temperate waters (southern Australia). Australian Journal of Botany 56: 437-450.

HenRich R. \& FreiWald A. 1995. - Controls on modern carbonate sedimentation on warm-temperate to Arctic coasts, shelves and seamounts in the northern hemisphere: implications for fossil counterparts. Facies 32: 71-108.

Hetzinger S., Halfar J., Riegl B. \& Godinez-Orta 
L. 2006. - Sedimentology and acoustic mapping of modern rhodolith facies on a non-tropical carbonate shelf (Gulf of California, Mexico). Journal of Sedimentary Research 76: 670-682.

Kleypas J. A., Feely R. A., Fabry V. J., Langdon C., SAbine C. L. \& Robbins L. L. 2006. - Impacts of ocean acidification on coral reefs and other marine calcifiers: a guide for future research. Report of a Workshop held 18-20 April 2005, St. Petersburg, FL, sponsored by NSF, NOAA, and the US Geological Survey. http:// www.ucar.edu/communications/Final_acidification.pdf

KuffNer I. B., ANDERsSON A. J., Jokiel P. L., RodGERS K. S. \& Mackenzie F. T. 2007. - Decreased abundance of crustose coralline algae due to ocean acidification. Nature Geoscience 1: 114-117. http:// dx.doi.org/10.1038/ngeo 100

Manker J. P. \& Carter B. D. 1987. - Paleoecology and paleogeography of an extensive rhodolith facies from the Lower Oligocene of south Georgia and north Florida. Palaios 2: 181-188.

Mutti E., Papani L., Di Biase D., Davoli G., Mora S., Segadelli S. \& TinterRi R. 1995. - Il Bacino Terziario Epimesoalpino e le sue implicazioni sui rapporti tra Alpi ed Appennino. Memorie di Scienze Geologiche 47: 217-244.

NEBELSICK J. H. \& BASSI D. 2000. — Diversity, growth forms and taphonomy: key factors controlling the fabric of coralline algae dominated shelf carbonates, in INSAlaco E., Skelton P. \& Palmer T. J. (eds), Carbonate platform systems: components and interactions. Geological Society of London, Special Publication 178: 89-107.

Orr J. C., Fabry V. J., Aumont O., Bopp L., Doney S. C., FeEly R. A., GNANADESIKAN A., Gruber N., ISHIDA A., Joos F., Key R. M., Lindsay K., Maier-Reimer E., Matear R., Monfray P., Mouchet A., NajJar R.G., Plattiner G.-K., Rodgers K. B., Sabine C. L., Sarmiento J. L., Schlitzer R., Slater R. D., TotTERDELl I. J., WeIRIG M.-F., YAMANAKA Y. \& YoOL A. 2005. - Anthropogenic ocean acidification over the twenty-first century and its impact on calcifying organisms. Nature 437: 681-686.

Pasceli C., Cabral D., Sissini M., Monteiro P., Ortigara G., Farias J., Riul P., Pagliosa P. \& Horta P. 2009. - Rhodolith bed community structure in the southern Brazilian coast. III International Rhodolith workshop, meeting programme and book of abstracts. Armação de Búzios, Brazil, 1-5 Dec. 2009.

Quaranta F., Vannucci G., Basso D. \& Piazza M. 2009. - Post-Symposium field trip guide, in BASSO D. \& BRACCHI V. (eds), Field trip guide-book of the 6th Regional Symposium of the International Fossil Algae Associaton, Milano, July 1-5, 2009. Annali dell'Università di Ferrara, Sezione Museologia Scientifica e Naturalistica, spec. vol. 2009: 15-25.

RASSER M. W. \& Piller W. E. 2004. - Crustose algal frameworks from the Eocene Alpine foreland. Palaeo- geography, Palaeoclimatology, Palaeoecology 206: 21-39. Riul P., Lacouth P., Pagliosa P. R., Christoffersen M. L. \& HorTA P. A. 2009. - Rhodolith beds at the easternmost extreme of South America: community structure of an endangered environment. Aquatic Botany 90: 315-320.

Rocha R. M., Metri R. \& OMURO J. Y. 2006. — Spatial distribution and abundance of ascidians in a bank of coralline algae at Porto Norte, Arvoredo Island, Santa Catarina. Journal of Coastal Research SI 39: 1676-1679.

Sarmiento J. L., Hughes T. M. C., Stouffer R. J. \& MANABE S. 1998. - Simulated response of the ocean carbon cycle to anthropogenic climate warming. Nature 393: 245-249.

Scoffin T. P., StOdDart D. R., Tudhope A. W. \& WoOdroffe C. 1985. - Rhodoliths and coralliths of Muri Lagoon, Rarotonga, Cook Islands. Coral Reefs 4: 71-80.

Steller D. L., Riosmena-Rodriguez R., Foster M. S. \& RoBERTS C. A. 2003. - Rhodolith bed diversity in the Gulf of California: the importance of rhodolith structure and consequences of disturbance. Aquatic Conservation: Marine and Freshwater Ecosystems 13: S5-S20.

Steller D. L., Foster M. S. \& Riosmena-Rodriguez R. 2007. - Sampling and monitoring rhodolith beds, in Rigby P. R., IKEN K. \& Shirayama Y. (eds), Sampling Biodiversity in Coastal Communities: NaGISA Protocols for Seagrass and Macroalgal Habitats. Kyoto University Press in association with NUS Press, Japan, 145 p.

Titschack J., Nelson C. S., Beck T., Freiwald A. \& RADTKE U. 2008. - Sedimentary evolution of a Late Pleistocene temperate red algal reef (Coralligène) on Rhodes, Greece: correlation with global sea-level fluctuations. Sedimentology 55: 1747-1776.

Turco E., Duranti D., Iaccarino S. \& Villa G. 1994. - Relationships between foraminiferal biofacies and lithofacies in the Oligocene Molare Formation and Rigoroso Marl: preliminary results from the Piota River section (Tertiary Piedmont Basin, NW Italy). Giornale di Geologia, ser. 3, 56 (2): 101-117.

VANNUCCI G. 1980. - Prime indagini sulle rhodoliti del "Serravalliano" della Valle Scrivia. Quaderni dell'Istituto di Geologia dell'Università di Genova 1 (5): 59-64.

Vervloet C. C. 1966. - Stratigraphical and Micropaleontological Data on the Tertiary of Southern Piemont (Northern Italy). Schotanus \& Jens, Utrecht, 88 p.

Webster J. M., Clague D. A., Braga J. C., Spalding H., Renema W., Kelley C., Applegate B., Smith J. R., Paull C. K., Moore J. G., Potts D. 2006. Drowned coralline algal dominated deposits off Lanai, Hawaii; carbonate accretion and vertical tectonics over the last 30 ka. Marine Geology 225: 223-246.

Submitted on 19 October 2011; accepted on 14 December 2011. 